\title{
Education in Denmark: Best Practices for Indonesia
}

\author{
Muhammad Thobroni ${ }^{1,2 *}$, Ida Zulaeha ${ }^{3}$, Hari Bakti Mardikantoro ${ }^{4}$, \\ and Tommi Yuniawan ${ }^{5}$
}

\author{
${ }^{1}$ Indonesian Language Education Department, Universitas Borneo Tarakan \\ 2, 3, 4, 5 Language Education Scince, Doctoral Programme, State University of Semarang \\ Corresponding Author*Email: thobroni@students.unnes.ac.id
}

\begin{abstract}
The quality of the population of a nation is influenced by many things, including: education, health and the level of economic income. Compared to developed countries, the level of education is very good and quality because it is supported by adequate educational facilities and infrastructure. In the era of globalization and the increasingly strong development of information technology today, relations between nations and countries are increasingly open and it is necessary to learn from each other, especially from developing and underdeveloped countries to more developed countries. Indonesia as a developing country can take that choice to study in a more advanced country as a step to adapt to the times so as not to be crushed by competition or isolated from world relations.

The article is an educational comparison study using the method of literature studies or literature studies on theories or data relevant to the objectives and problems studied. The topic studied was education in Denmark with the aim of exploring good practices that can be adapted for education in Indonesia. The focus study examines concepts, theories and literature-sourced data, such as sites, books, journals, and so on published in print or online. Meanwhile, the method of collecting data from the data source of this research is documentation, by making documents or records as data sources and the contents of records become the subject of research or variables. This article is interested in comparing education between Denmark and Indonesia with the following considerations. First, the political and regulatory systems between Denmark and Indonesia are very different, so it is interesting to compare them with each other in order to find gaps and red threads in improving education in Indonesia with the existing regulatory situation. Second, comparative studies of education between Denmark and Indonesia are still very rare, so it is very interesting to make comparisons of education in order to take good practices (best practices) from other countries with more advanced education, such as Denmark, to adopt and adapt several things that can be implemented in policy and practice. Third, Denmark and Indonesia have different socio-cultural and political systems although based on the same spirit, namely democracy, but have different socio-cultural roots and national ideologies. This is an interesting reason for the need to compare education in Denmark and Indonesia in terms of making the socio-cultural roots and the roots of the national system as the basis for formulating the national education system, especially the literacy movements in their respective countries.
\end{abstract}

\section{Keywords: Literacy Education in Denmark, Literacy Education in Indonesia}

\section{INTRODUCTION}

Explains that the quality of the population of a nation is influenced by many things, including: education, health and the level of economic income. Some of these are interrelated and somewhat difficult to separate from one another (Sukmayani, 2008)[1]. Quality education in a country is characterized by several things such as low literacy rates, very high education completion rates, and school age status, namely school participation of the population of school age is quite high and even all of them get school services. The lack of quality of education 
in a country is influenced by several factors, such as: 1) low levels of income that cause parents to be unable to send their children to higher levels; 2) lack of public awareness about the importance of going to school; 3) educational facilities and infrastructure are still not given enough attention; 4) the number of school infrastructure and the number of school age students is still not balanced. Compared to developed countries, the level of education is very good and quality because it is supported by adequate educational facilities and infrastructure.

The condition of education in Indonesia is still unsatisfactory and quality lags behind other more developed countries with some evidence. First, Indonesia according to UNESCO is the 10th country out of 14 developing countries. Second, one of the components of education, namely Indonesian teachers ranks 14 out of 14 developing countries. That is why there is a need for Indonesia to immediately respond to its national education problems so that it can compete with other countries in coloring world civilization. It is realized that the future of a country is currently very much influenced by the development of resources and science and technology in the country (Hidayat, 2016)[2].

In the era of globalization and the development of increasingly strong information technology, relations between nations and countries are increasingly open and it is necessary to learn from each other, especially from developing and underdeveloped countries to more advanced countries. Indonesia as a developing country can take that option to study in a more advanced country as a step to adapt to the times so that it is not crushed by competition or isolated from world relations. The government and the people of Indonesia need to keep open concern for the progress of developed countries and there is no need to stop or shut out the positive influence of these developed countries. The government and the people of Indonesia can learn many positive, creative and innovative things from developed countries regarding how they organize themselves so that they are able to achieve the development of superior science, technology and cultural arts. In fact, by studying in developed countries, Indonesia can respond and anticipate future developments so that it is able to become a player or actor capable of coloring the development of the world such as the greatness and glory of Indonesia when it was still an archipelago (Simanjuntak, 2007).[3]
This article is interested in comparing education between Denmark and Indonesia with the following considerations. First, the political and regulatory systems between Denmark and Indonesia are very different, so it is interesting to compare them with each other in order to find gaps and red threads in improving education in Indonesia with the existing regulatory situation. Second, comparative studies of education between Denmark and Indonesia are still very rare, so it is very interesting to make comparisons of education in order to take good practices (best practices) from other countries with more advanced education, such as Denmark, to adopt and adapt several things that can be implemented in policy and practice. Third, Denmark and Indonesia have different socio-cultural and political systems although based on the same spirit, namely democracy, but have different socio-cultural roots and national ideologies. This is an interesting reason for the need to compare education in Denmark and Indonesia in terms of making the socio-cultural roots and the roots of the national system as the basis for formulating the national education system, especially the literacy movements in their respective countries.

A study of education in Denmark was conducted (Bugge, 2006) [4] which found that in Danish schools, moral education has never been a separate subject as a shared function or alternative to religious education. Nevertheless, the need for moral education programs in schools continues. The teachers were well prepared, although doubts and problems arose in their implementation, such as the development of pupils' attitudes. In contrast to the research, this article emphasized on aspects of Danish education culture to build character education, literacy, digitalization of education that can be adapted to Indonesian education. Comparative studies from Denmark are new studies in terms of character education, literacy and digitization of education to be adapted in Indonesian education.

Another relevant study was conducted by (Foldberg, 2006)[5] which focused on efforts to illustrate the national roots of Danish teacher education as regulated by parliamentary law, and listed the types of institutions that provide teacher education for various forms of schools. The article focuses on reviewing the education of primary and secondary teachers, primary and secondary schools, 6-16 age ranges in universities equivalent to universities. The article describes the educational aspects of Danish teachers as subject managers. This 
comparative study sees the article can be used as a material for developing character education and literacy, which is an important thing to be considered in education in Indonesia.

These studies have been conducted for many years and need to be done more recent studies on education in Denmark so that the study of this article can fill the gap in the study of education in Denmark in a cutting-edge context. In addition, this article can also add to the study treasures that compile education in Denmark to be adapted in education in Indonesia. Comparative studies of other countries such as Denmark to be adapted in education in Indonesia can have a positive influence on the development of Indonesian education in general, especially related to character education, literacy and educational digitalis.

\section{METHOD}

This article is an educational comparison study using the method of literature studies or literature studies on theories or data relevant to the objectives and problems studied. The topic studied was education in Denmark with the aim of exploring good practices that can be adapted for education in Indonesia. The focus study examines concepts, theories and literature- sourced data, such as sites, books, journals, and so on published in print or online. It is in accordance with (Sujarweni, 2014) [6] explanation that the study of the library serves to strengthen the concept or theory as the basis of research studies. It also aims to develop aspects of theory and practical benefits (Sukardi, 2013).[7] As a library study, this article undergoes library research as described by (Dzakiyyah, 2017)[8] namely research conducted by means of data collection or scientific papers with the appropriate purpose of research objects or literature, or study with the aim of finding solutions based on critical studies of relevant library materials.

Researchers need to know the source of information obtained such as; textbooks, scientific journals, statistical conferences, research results in the form of thesis, thesis, dissertation, and the internet, as well as other relevant sources (Sanusi, 2016)[9]. An additional explanation was given by Sanusi that this kind of descriptive research focuses on systematically explaining facts.

Meanwhile, the method of collecting data from the data source of this research is documentation, by making documents or records as data sources and the contents of records become the subject of research or variables (Arikunto, 2006)[10]. Data sources studied using primary sources are sources that provide data directly from first hand or original sources (Nasution, 2001)[11].

\section{FINDING AND DISCUSSION}

According to the 2018 survey, Denmark was the first best practice country in terms of implementing The E-Government Development Index (EGDI). Research conducted independently by UNDESA, Denmark received the highest score of 0.9150 . Denmark has also implemented a 2016-2020 digital strategy by determining the direction of digitizing the public sector, as well as government interactions with society, industry and business (Napitupulu, 2020).[12]

It is interesting to make comparisons of education between Denmark and Indonesia in the following sections.

1. Demography

Denmark is located in the south of the Scandinavian countries with an area of 43,092 $\mathrm{km}$, and the largest population age is 15 years of only $18 \%$ and a life expectancy of 78.2 years. Danish citizens consist of Denmark 91, 2\%, Faroe $0.9 \%$, Greenland $0.1 \%$, with foreign nationals $7.8 \%$ with a European composition of $3.3 \%$, Middle East and Asia 4.4\%, and Africa $0.1 \%$. Denmark is a country with a literate rate of $99 \%$. While the official language used is Danish, with 13 languages, and 7 native languages. Denmark relies heavily on the service sector, environmental innovation, agriculture, fisheries and light industry, with its social security system taxed very heavily. In the political system, Denmark adheres to a constitutional monarchy with a stable parliamentary democratic system of government. The country is a member of the European Union which is known to be very smart and careful in international struggles and emphasizes its independence as a country. In this country, freedom of religion is fully recognized even though the Lutheran church is recognized as the national church (Mandrik, 2013).[13]

Compared to Denmark, Indonesia has a much wider area, a much more heterogeneous citizenry with hundreds of ethnic groups spread over different geographies, with a much more varied occupation with all the complex economic problems. In the political system, Denmark is a good example of how state stability is guaranteed 
so that people feel comfortable and public services can run in a quality manner. The modified form of a democratic state in the form of a monarchy with the support of a loyal but critical parliament has enabled Denmark to become a stable country so that it is conducive to thinking about the needs of its citizens, including education services. With the freedom of religion that it adheres to, it shows that Denmark has finished with sensitive matters and issues related to the religion and spirituality of its citizens, so that it does not interfere with the running of government, educational interests and other interests in the social, political and economic fields. This condition is of course somewhat different from Indonesia where religion is still a sensitive issue and has become an important part of many debates and discussions of the community, nation and state related to education, economy, social, politics and other fields from the past to the present.

2. Educational System

Denmark adheres to a liberal democratic social political system. The education system built leads to the liberalism education system and encourages the importance of national education to respond to economic globalization. This necessitates Denmark as an open nation-state to accept the wave of educational liberalization with a market and economic orientation as well as commander.

In Putra's explanation, globalization allows the liberalization of other fields including national education in which nation-states embrace the major currents of change in world civilization (Putra, 2016).[14] In this regard, the phenomenon of globalization and liberalization also affects higher education, as indicated by the mystification of participation in higher education, increased demand for higher education, changes in the role of the state in the implementation of higher education, international student mobility, knowledge based economy, profit-oriented universities, the field of higher education. Education as part of the service industry, and the management of higher education is influenced by the principles of liberalism.

In Putra's explanation also, globalization allows the liberalization of other fields including national education in which nation-states embrace the major currents of change in world civilization. In this regard, the phenomenon of globalization and liberalization also affects higher education, as indicated by the mystification of participation in higher education, increased demand for higher education, changes in the role of the state in the implementation of higher education, international student mobility, knowledge based economy, profit-oriented universities, the field of higher education. Education as part of the service industry, and the management of higher education is influenced by the principles of liberalism.

The state and national political system based on Pancasila has become the distinctive color of Indonesia in democratic practices among developed countries in the world of democracy adherents; one side is a real example for countries with acute conflicts such as Afghanistan and Iraq, including countries with the threat of radicalism, fundamentalism and extremism leading to terrorism, which makes Indonesia a unique model. But on the other hand, the Pancasila political system also provides a dialectical and exhausting process of state and nation to date, which also influences the formulation and implementation of the national education system.

The debate on basic concepts and the application of the national education system in Indonesia is still ongoing even though it is clearly regulated in the laws and regulations, namely Law No. 23 of 2003 on the National Education System with all its derivative regulations. However, the change in national education as a practice has not been easy, marked by protests from community organizations, political organizations, and student demonstrations. The real phenomenon of the complexity of implementing the national education system in Indonesia can be seen in education in a pandemic era such as today, the phenomenon of the Mobilizing Teacher program (Program Guru Penggerak), the concept of Free Learning (Program Merdeka Belajar), or the legal status of BHMN for universities. The debate generally occurs between the views stating that Indonesia's national education should be pushed towards educational liberalization or educational democratization as part of the participation of the current globalization of world civilization. On the other hand, national education is required to be at the vanguard of basic education services and changes in Indonesian society which are still marked by socio-economic and socio-political imbalances.

The above debate is also added to the sensitive issue that a national education that is too liberal is feared to be dragged down by Western and secular currents, while Indonesia is known as a religious nation. This is shown by historical evidence that national education relies heavily on education managed by Muhammadiyah 
community organizations in urban areas and Jamiyah NU in rural areas which are very popular and accepted by the wider community, plus education managed by Taman Siswa and the church-based Catholic Network. The situation of Indonesian national education until now seems not easy to adopt, adapt and at the same time respond to world developments not only due to economic affairs, but religious issues and religiosity as the basis for character building for Indonesian society with a religious and Eastern culture.

3. Human Resources Development, Literacy and Character Education

From data from the Central Statistics Agency (BPS) in 2018, Indonesia's Human Development Index (HDI) has reached 71, 39 in the high human development category, up from 2010 which only reached 66.53 . However, out of 34 provinces, only 9 provinces have indexes above the national average are West Sumatra, Riau, Riau Islands, DKI Jakarta, DI Yogyakarta, Banten, Bali, North Sulawesi and East Kalimantan. In 2010, there were still areas with low human development, namely West Sulawesi, East Nusa Tenggara, Papua and West Papua. In 2018 there were no provinces with low human development status. However, the HDI only measures the level of education and length of schooling, not the quality of education. The education level of the population is not accompanied by the quality level of education. There are even findings that the workforce of higher education graduates in Indonesia is equivalent to the workforce of high school graduates and below in Denmark. The Human Development Index Report issued by the United Nations in 2019, Denmark is included in the very high human development group and is ranked 11 th out of all countries in the world. Meanwhile, Indonesia, in the same year's report, was ranked 111 in the high human development category, behind Libya (110) which was currently in political conflict, Uzbekistan (109) and Turkmenistan (108) which was a splinter of the Soviet Union. Indonesia's 2019 HDI position above Samoa (ranked 112), South Africa (113), Bolivia (114), Gabon (115) and Egypt (116).

The score for the Program for International Students Assassement (PISA) for Indonesia in 2016 did not experience significant development for 15 years, still below 400. All countries that have joined the Organization for Economic Co-operation and Development (OECD) have an average of over 500. PISA scores Indonesia for mathematics 386 and for reading 397 (Harmadi, 2020).[15] PISA is an international assessment method that is an indicator for measuring the competence of Indonesian students at the global level. Kompas.com's publication related to PISA 2018 on literacy, mathematics and science, Indonesia is in the 70th place with an average of 396 , below Bosnia (67th with a mean of 398), Azerbaijan (68th with 398 mean), Kazasktan (69 with 398 mean 397). Indonesia is above Saudi Arabia (ranked 71 with a mean of 386), Lebanon (ranked 72 with a mean of 384), Georgia (ranked 73 with a mean of 383). While Denmark is in 24th place with an average of 493, below Switzerland (23rd with a mean of 495), Ireland (22nd with a mean of 496), Denmark is still above France (25th with a mean of 493), Portugal (26th, mean 492).

Based on research by Central Conference State University (CCSU) in 2016, Indonesia is ranked 60th out of 61 countries in terms of reading interest. The five best countries with reading interest are Finland, Norway, Iceland, Denmark and Sweden. CCSU research includes five variables, namely the number of libraries, newspapers, the education system (input), the education system (output), and the availability of computers. This should be a concern, even though Indonesia already has a School Literacy Movement policy that is strengthened by Permendikbud Number 23 of 2015 concerning Character Development (Napitupulu, 2020).[12]

Compared to the conditions of education in Indonesia, there are other similarities and differences from education in Denmark such as the application of character values to students. There are several records of Danish education that can be used as best practices for Indonesian education (White, 2005)[16]. First, Danes generally create laws that emphasize collective, not individual achievement. In practice, when a student has passed a certain material and subject they are directed to be able to help other students to achieve the same competence. Second, students are not directed to gain self-respect at the expense of other students. Third, Danish students are directed to be inclusive and understand the broad, complex context of life and respect for diversity, consensus politics and not identity politics and hate speech to other students. Fourth, class facilities are very abundant, the classroom atmosphere does not prioritize formality, and the number of students is very minimal. Fifth, education in Denmark emphasizes the critical 
attitude of students, but on the other hand they still adhere to traditional-conventional ways of thinking. Classroom learning is characterized by having a lot of class instructions, students sitting facing the blackboard and group work which is unusual compared to other countries. The learning phenomenon in the classroom is referred to as "somewhat boring". It is not easy to find noise in class, increased enthusiasm for learning, or an exchange of opinions between students and teachers.

Education in Denmark places great emphasis on the development of personality traits and the affective domain. Learning emphasizes the importance of children learning to get along with others and accept differences. Students are directed to be able to carry out dialogue and compromise on differences of opinion with other people who have other opinions. Students who have grown up, around the age of 16 years, have been introduced to the importance of selfunderstanding that the champion of material or lessons in class or school is not the main measure that the person concerned is the best human being compared to others.

Meanwhile, elementary school students of around 7-8 years old are prioritized to attend and feel at home in school first. At the age of 13 years of secondary education, students are introduced to freedom of thought, namely "what is felt is the same as what is thought". Upper-level education is directed so that students understand their identity as humans who have an active role in society after graduating from school and need to realize their hopes as individuals.

Despite emphasizing the affective aspect, Danish people do not ignore cognitive factors. Since pre-school, children have been conditioned to hone their cognitive skills through games and practice experimenting through educational media. Preschool and kindergarten children are encouraged to "learn by doing". Reading and writing are not taught during preschool and kindergarten, but can be taught when children are 7 years old or elementary school in formal education.

The curriculum is formulated by giving local authorities and schools space to interpret the curriculum that has been set nationally by the central government. Meanwhile, the national curriculum sets the goals and objectives for each subject and at every level. Schools have broad and great opportunities to understand, contextualize and implement appropriate curricula and learning methods for students to be able to achieve subject objectives. Teachers work comfortably and professionally because they are respected and maintain dignity in the school community and society, and many Danish schools involve community members whose children attend school to be involved and provide input to the curriculum. In this case, it appears that parents have a strong power over the curriculum and learning expectations in schools.

The Danish government and society value education very much so it is very supportive of education funding. Teachers and staff have a very large opportunity for personal development such as training. Relationships between students, teachers, school administrators and student guardians are very much maintained, even they have a meeting every year to stay overnight in a place live in, whether it is in the context of social or cultural activities.

Education in Denmark places great importance on the culture and way of life of its people. They transform oral traditions and mythology as part of their activities at school. Historical values are maintained as learning materials by explaining the war, defeat and superiority of Denmark as part of the cultivation of Danish nationalism based on the superior Scandinavian myth. Students are taught to care about the environment around them, the development of their country and nation, participate in the development of community democracy, and take responsibility for public problems. School learning is built within the framework of intellectual independence and democracy.

From media publications, it was found that the Indonesian government through the Ministry of Education and Culture in 2018 conducted a study in Denmark. The comparative education study in Denmark is based on the consideration that Denmark is ranked 5th in the HDI of all countries in the world. Based on a comparative study, the government found the uniqueness of Danish educators, including: 1) Playing while learning; 2) Combining the curriculum with digital resources; 3) Balance of Formal and Nonformal Education; 4) Collaboration with Corporations; 5) Maintaining Cultural Values ("Skor Pisa 2018: Peringkat Lengkap Sains Siswa Di 78 Negara, Ini Posisi Indonesia," n.d.)(Kompas, 7 September 2018).[17]

Another thing that can be found from Denmark regarding literacy is the abundant availability of books in libraries that are available 
to remote areas. Books on skills that support everyday life, books about skills needed for work, children's books including picture books used by early childhood, fiction books for children aged 712 years, novels for children aged 13- 18 years old, adult novels, family books and so on. Denmark emphasizes the importance of literacy being introduced from an early age in schools and communities so that facilities that support literacy are abundant.

Children in Denmark are introduced to books from a young age, shown that books are fun and can be a great study partner. Literacy is built as a policy, supported by an adequate budget, provided quality human resources, and services that are easily accessible to children at any time. In Denmark, children are familiar with reading and counting books in the form of books equipped with supporting pictures, some books lifting local wisdom, and introducing language with unique packaging. The government strongly supports the competence of Danish language for children including their local language as a pride and great cultural identity of their nation.

Children in Denmark are introduced to books from a young age, shown that books are fun and can be a great study partner. Literacy is built as a policy, supported by an adequate budget, provided quality human resources, and services that are easily accessible to children at any time. In Denmark, children are familiar with reading and counting books in the form of books equipped with supporting pictures, some books lifting local wisdom, and introducing language with unique packaging. The government strongly supports the competence of Danish language for children including their local language as a pride and great cultural identity of their nation.

Literacy development in Denmark is an interesting best practice for literacy development in Indonesia, especially in relation to several things. First, the relationship between literacy and the conservation of the surrounding natural environment; second, the connection between literacy and local wisdom, such as the original Danish language and local folklore as writing material. Third, the availability of illustrated children's books and other literacy support books for early childhood is very abundant. Fourth, Denmark's courage in utilizing digital technology for everyday life, including in education and literacy. Denmark has mainstreamed digital technology and carried out digitalization programs in all areas of life services, including government services (e-government) so that it is a country with a high number of transparency for government services.

\section{CONCLUSION}

Denmark is a developed country that can become a role model and best practice for Indonesia in developing national education as an effort to become a dignified developed country in the world social arena. The progress of a nation and state needs to be encouraged, planned, evaluated and coached in a visionary development system, including moving the education sector as the pillar of development.

However, not all values that are applied in the life of Denmark as a state and nation can be fully applied in Indonesia which is wider, more diverse and more complex in many ways. Indonesia needs to explore positive, creative and innovative values from Denmark so that it can be modified, adapted and adapted in an Indonesian context that has historical roots in the past in order to build Indonesian civilization today and to meet the future.

Education studies in Denmark can be recommended to be adapted in the development of education in Indonesia, especially character education, literacy and digitization of education. In terms of character education, Danish character education is carried out in a massif by exploring ancestral heritage such as folklore, language and literature that strengthen Danish nationality. Indonesia has many ancestral heritage related to language and literature in various regions that can be used as a source of education of the nation's superior character. Character education in Denmark is the spirit of all learning, not taught as a special subject. In addition, literacy culture has been carried out in Denmark from an early age, through a pleasant education, the availability of illustrated children's books, literature introduced from childhood, a fun learning environment, and a culture of reading and writing has been built early on. Literacy culture in Denmark can be adapted to foster literacy in Indonesia by providing early childhood reading books in schools and communities, such as picture books, story books, children's dictionary, and so on. Another thing that can be recommended is the importance of digitization in all areas that Denmark has done since 2015 including education. Digitalization aims to facilitate and transparency of public services. It can be applied in Indonesia not only because of the Covid 19 pandemic but the need for the development of 
industrial revolution 4.0 that allows digital use in education.

One example of educational adaptation in Denmark related to character education, literacy and digitization of education is the model of language conservation with minority speakers in the form of illustrated children's electronic dissies to improve early childhood literacy in North Kalimantan. According to (Thobroni, Muhammad; Zulaeha, n.d.)[18], the illustrated children's electronic dictionary is a manifestation of some contemporary educational spirit. First, conservation-minded education. In this case, the electronic dictionary of children with pictures is used as a vehicle for socio-cultural conservation including language conservation. Second, in addition to containing vocabulary that is a reflection of the natural environment and sociocultural environment of its people, electronic disuses are also equipped with images that show local cultural wisdom. It can be used to build the character of early childhood through the transformation of local culture which is an ancestral heritage to build a superior generation. Third, the electronic dictionary of illustrated children can be used for civic literacy, because it contains vocabulary and images that are the identity of national and regional pride that distinguishes from other countries on the border of North Kalimantan. Fourth, illustrated children's electronic dictionary can be used to improve basic literacy in the form of vocabulary recognition for early childhood. The dictionary also features interesting images, sounds and colors that are specially packaged for early childhood. It is part of the provision of interesting literacy reading materials for early childhood, namely picture children's books packed in digital rides. Fifth, children's electronic dictionary can be used to improve children's digital literacy from an early age, so that children can utilize digital technology for positive and healthy activities, such as education, online socialization, and other needs.

\section{REFERENCES}

[1] Sukmayani. (2008). Ilmu Pengetahuan Sosial 3 untuk SMP/MTs Kelas IX (Indonesia). Pusat Perbukuan, Kementerian Pendidikan dan Kebudayaan.

[2] Hidayat. (2016). Rekontruksi Paradigma Pendidikan. CV. Social Politics Genius.
[3] Simanjuntak. (2007). Pendidikan Kewarganegaraan SMP/MTS Kelas IX. Grasindo.

[4] Bugge. (2006). Moral Education in Denmark: Problems and Possibilities. Journal of Moral Education, Volume 17. https://doi.org/10.1080/0305724880170 $\underline{107}$

[5] Foldberg. (2006). Teacher Education in Denmark. European Journal of Teacher Education, Volume 8,. https://doi.org/10.1080/0261976850080 302

[6] Sujarweni. (2014). Metodeologi Penelitian. Pustaka Baru Press.

[7] Sukardi. (2013). Metodologi Penelitian Pendidikan Kompetensi dan Praktiknya. Bandung: Bumi Aksara.

[8] Dzakiyyah. (2017). Jenis Penelitian.Bandung: Rinekacipta.

[9] Sanusi. (2016). Metodologi Penelitian Bisnis. Jakarta: Salemba Empat.

[10] Arikunto. (2006). Prosedur Penelitian Suatu Pendekatan Praktik. Bandung: Rieneka Cipta.

[11] Nasution. (2001). Metode Reseach Penelitian Ilmiah, Edisi I. Jakarta: Bumi Aksara.

[12] Napitupulu. (2020). Menulis Artikel Ilmiah untuk Publikasi. Yayasan Kita Menulis.

[13] Mandrik. (2013). Operation World: Panduan untuk Mendoakan Semua Bangsa di Dunia (Edisi ke-7). Katalis Media \& Literature - Yayasan Gloria.

[14] Putra. (2016). Politik Pendidikan, Liberalisasi Pendidikan Tinggi di Indonesia dan India. Yayasan Pustaka Obor Indonesia.

[15] Harmadi. (2020). Population Policy. Jakarta: Elex Media Komputindo. 
[16] White. (2005). Curriculum Innovation: A Cellebration of Classroom Practice, Pembaharuan Kurikulum Sebuah Perayaan Praktik Kelas. Grasindo.

[17] Thobroni, Muhammad; Zulaeha, I. (n.d.). KAMUS ELEKTRONIK ANAK SEBAGAI KONSERVASI BAHASA DAERAH DAN MEDIA PEMBELAJARAN ELEKTRONIK DI ERA PANDEMIK COVID 19. Prosiding Seminar Nasional Pascasarjana Universitas Negeri Jakarta,188-195.

http://journal.unj.ac.id/unj/index.php/se mnas-ps/article/view/16876 